PTK, Vol.2 No.1 2021

ISSN: 2747-1977 (Print) / 2747-1969 (Online)

DOI: https://doi.org/10.53624/ptk.v2i1.44

\title{
Peningkatan Hasil Belajar Siswa pada Materi Bagian Tumbuhan melalui Metode STAD di Kelas IV SDN 1 Joho Kecamatan Pace Kabupaten Nganjuk
}

\author{
Diterima: \\ 2 Januari 2021 \\ Revisi: \\ 26 Januari 2021 \\ Terbit: \\ 1 Februari 2021
}

\author{
Febriani Nur Fatimah \\ SDN 1 Joho, Pace \\ Nganjuk, Indonesia \\ E-mail:febriani.nur.091644049@gmail.com
}

\begin{abstract}
Abstrak - Materi pembelajaran Ilmu Pengetahuan Alam di tingkat Sekolah Dasar cukup luas. Pada proses pembelajaran perlu adanya bantuan media konkret untuk merangsang anak terlibat secara aktif dan bersemangat dalam kegiatan individu atau kelompok. Pada kegiatan pembelajaran peneliti menemukan bahwa tingkat pemahaman tentang bagian-bagian tumbuhan dan fungsinya siswa kelas IV SD Negeri 1 Joho masih rendah dikarenakan guru menjelaskan dengan ceramah dan contoh yang abstrak sehingga siswa kesulitan memahaminya. Berdasarkan temuan tersebut, maka tujuan penelitian ini adalah melakukan pemecahan masalah melalui penerapan metode STAD (Student Teams Achievement Divisions). Penelitian ini menggunakan rancangan penelitian tindakan kelas yang terdiri dari dua siklus. Pada masing -masing siklus dilakukan tahap perencanaan, pelaksanaan tindakan, observasi, dan refleksi. Subyek penelitian adalah siswa kelas IV SD Negeri 1 Joho dengan jumlah siswa 19 anak. Berdasarkan hasil penelitian yang telah dilakukan secara sistematis dapat disimpulkan bahwa pelaksanaan pembelajaran Ilmu Pengetahuan Alam dengan materi bagian-bagian tumbuhan dan fungsinya yang menerapkan pembelajaran dengan penerapan metode STAD dapat mengoptimalkan pembelajaran di kelas. Salah satunya meningkatkan hasil belajar siswa. Hasil belajar siklus I sebesar $65 \%$ meningkat menjadi $96 \%$ pada siklus II atau mengalami peningkatan $31 \%$. Jadi, dapat disimpulkan bahwa metode STAD ini termasuk metode pembelajaran yang dapat meningkatkan aktivitas dan hasil belajar siswa.
\end{abstract}

Kata Kunci - hasil belajar, materi, metode STAD

\begin{abstract}
Natural Science learning materials at the elementary school level are quite extensive. In the learning process, it is necessary to have concrete media assistance to stimulate children to be actively and enthusiastically involved in individual or group activities. In the learning activities, the researchers found that the level of understanding of plant parts and their functions was still low for fourth grade students of SD Negeri 1 Joho because the teacher explained with lectures and abstract examples so that students had difficulty understanding them. Based on these findings, the purpose of this study is to solve problems through the application of the STAD (Student Teams Achievement Divisions) method. This study used a classroom action research design consisting of two cycles. In each cycle, the stages of planning, implementing actions, observing, and reflecting are carried out. The research subjects were fourth grade students of SD Negeri 1 Joho with 19 students. Based on the results of research that has been carried out systematically, it can be concluded that the implementation of learning Natural Sciences with the material of plant parts and their functions that apply learning by applying the STAD method can optimize learning in the classroom. One of them is improving student learning outcomes. The learning outcomes of the first cycle of $65 \%$ increased to $96 \%$ in the second cycle or an increase of $31 \%$. So, it can be concluded that the STAD method is a learning method that can increase student activity and learning outcomes.
\end{abstract}

Keywords - learning outcomes, materials, STAD method 
ISSN: 2747-1977 (Print) / 2747-1969 (Online)

DOI: https://doi.org/10.53624/ptk.v2i1.44

\section{PENDAHULUAN}

Ilmu Pengetahuan Alam merupakan cabang ilmu pengetahuan yang mempelajari tentang fenomena-fenomena alam. Pembelajaran IPA merupakan suatu pelajaran agar siswa berfikir secara ilmiah dan logis. Pelajaran IPA di tingkat Sekolah Dasar merupakan mata pelajaran yang mencakup materi cukup luas. Guru diwajibkan menuntaskan target ketuntasan belajar siswa, sehingga memerlukan perencanaan dan pelaksanaan pembelajaran dengan menggunakan media atau alat peraga, strategi belajar dan metode yang tepat dan sesuai. Guru harus mampu memberikan rangsangan kepada siswa agar bersemangat dalam mengikuti pembelajaran (Lubis 2020).

Pembelajaran IPA pada kenyataan masih banyak guru yang menyampaikan materi menggunakan metode yang kurang tepat sehingga hasil atau prestasi belajar siswa dalam mata pelajaran masih belum memuaskan dan jauh dari yang diharapkana. Pada proses pembelajaran guru hanya menggunakan metode ceramah dan tidak menggunakan media atau alat bantu dalam menyampaikan materi. Hal ini banyak dikeluhkan oleh guru, kurang berhasilnya pembelajaran IPA karena guru monoton dan tidak menggunakan metode yang tepat.

Upaya yang dilakukan guru agar siswa dapat memahami materi pelajaran yaitu menggunakan alat peraga atau yang sering disebut dengan media. Media yang digunakan pastinya beragam dan berbeda-beda. Pemilihan media hendaknya disesuaikan dengan kebutuhan tingkatan usia peserta didik dan mata pelajaran yang sedang dipelajari (Simarmata et al. 2020). Dengan menggunakan media siswa sekolah dasar akan lebih memahami, mengerti dan memaknai materi yang sedang ia pelajari sehingga terbentuk konsep atau pemikiran yang bersifat kekal dan tak mudah dilupakan karena telah tertanam konsep yang kuat dan matang dalam diri siswa.

Media konkret diharapakan mampu menjadi solusi yang tepat untuk mengatasi rendahnya hasil belajar IPA khususnya pada siswa kelas IV SD Negeri 1 Joho. Berdasarkan hasil observasi peneliti pada pembelajaran IPA tentang Pemanfaatan Sumber Daya Alam diperoleh data bahwa dari 19 siswa terdapat 5 siswa yang telah mencapai KKM dan 14 sisanya belum mampu mencapai KKM yang telah ditetapkan yaitu 65. Dengan demikian dapat diartikan bahwa kemampuan memahami konsep pembelajaran tentang Pemanfaatan Sumber Daya Alam siswa hanya berkisar $30 \%$.

Berdasarkan uraian diatas, maka perlu dilakukan suatu tindakan pembelajaran pada siswa kelas IV SD Negeri 1 Joho untuk dapat menyelesaikan permasalahan pembelajaran dikelas dalam mata pelajaran IPA materi bagian-bagian dan fungsi tumbuhan. Salah satu aspek yang diperbaiki adalah dalam proses pembelajaran menggunaan media konkret dengan metode pembelajaran kooperatif type STAD (Slavin 2010; Trianto 2009; Trianto 2007). 
PTK, Vol.2 No.1 2021

ISSN: 2747-1977 (Print) / 2747-1969 (Online)

DOI: https://doi.org/10.53624/ptk.v2i1.44

\section{METODE}

Prosedur penelitian perbaikan pembelajaran ini dirancang 2 siklus yang diawali dengan prasiklus kemudian siklus 1 sebagai perbaikan prasiklus dan apabila ditemukan masalah dilanjutkan pada siklus 2. Siklus yang berakhir jika masalah telah tuntas penyelesainnya. Prosedur penelitiannya akan dilakukan 4 tahapan yaitu perencanaan, pelaksanaan tindakan, observasi/pengamatan, evaluasi-refleksi (Iskandar 2009).

Dalam pelaksanaan penelitian tindakan kelas, ada dua jenis data yang dikumpulkan peneliti yaitu data kualitatif dan kuantitatif. Dimana nantinya kedua jenis analisis cara pengumpulan data tersebut dapa dijadikan patokan atau aturan suatu hasil yang diperoleh peniti dalam membandingkan pembelajaran. Adapun cara mengolah data tersebut adalah sebagai berikut: 1) Data Kualitatif, Data kualitatif diambil dari hasil pengamatan keaktifan siswa dalam proses pembelajaran. 2) Data Kuantitatif, Data kuantitatif berupa hasil tes yang dikerjakan siswa diakhir peroses pembelajaran. Data yang diperoleh dari hasil tes siswa berupa data kuantitatif dan data kualitatif.

\section{HASIL DAN PEMBAHASAN}

Pada awal kegiatan guru menyampaikan materi fungsi bagian-bagian tumbuhan, dimana dalam materi ini mencangkup fungsi bagian tumbuhan, bagian-bagian daun dan jenis-jenis daun. Dalam hal ini guru menerangkan menggunakan metode ceramah.

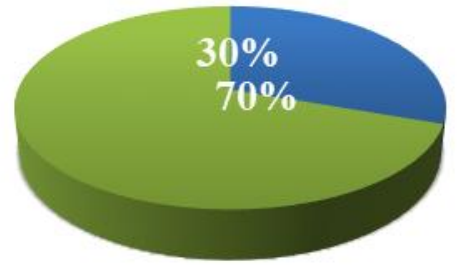

Tuntas

- Tidak Tuntas

\section{Gambar 1. Ketuntasan Belajar Siswa Tahap Pra Siklus}

Berdasarkan gambar 1 dapat disimpulkan bahwa siswa yang mencapai KKM adalah 5 anak (30\%) dan nilai rata-rata siswa kelas VI SD Negeri 1 Joho adalah 57. Hasil tersebut menunjukan bahwa ketuntasan siswa secara individu masih rendah, sehingga akan dijadikan perbandingan untuk upaya peningkatan prestasi belajar menggunakan media konkret dengan metode STAD pada pembelajaran Ilmu Pengetahuan Alam (fungsi bagian-bagian tumbuhan) pada siklus I. Guru masih mendominasi proses pembelajaran yang membuat siswa cendrung pasif. Metode 
yang digunakan masih belum tepat.

\section{SIKLUS I}

Peneliti melakukan perbaikan pembelajaran yang meliputi Rencana Perbaikan Pembelajaran (RPP) dan lembar soal kelompok yang nantinya dapat dijadikan acuan cara melihat karakter siswa dan penilaian kinerja siswa melalui lembar observasi. Berdasarkan pelaksanaan perbaikan pembelajaran tersenut, diperoleh hasil sebagai berikut :

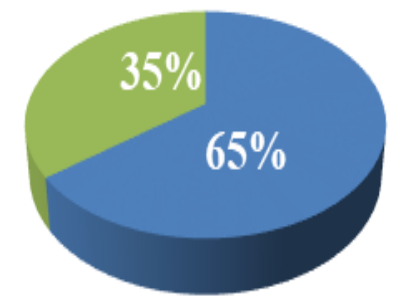

\section{- Tuntas - Tidak Tuntas}

\section{Gambar 2. Ketuntasan Belajar Siswa Tahap Siklus I}

Berdasarkan gambar 2 yang sudah dilaksanakan menunjukan adanya peningkatan nilai yang baik. KKM yang telah ditentukan dari sekolah yaitu 65. Siswa yang mencapai KKM adalah 12 anak $(65 \%)$ dan rata-rata nilai siswa kelas VI adalah 64.

Berdasarkan data tersebut dapat ditarik kesimpulan bahwa pada siklus I siswa mulai tertarik, karena guru menggunakan media baru dalam pembelajaran dan serta data kriteria observasi hasil belajar yang dilihat tergolong cukup. Siswa mulai memahami materi yang telah diberikan, namun masih memiliki kekurangan dalam membedakan dan mengelompokkan jenis-jenis daun. Siswa sudah dapat berkolaborasi dengan temannya walaupun ada beberapa yang masih terlihat diam. Secara garis besar Siklus I berjalan dengan baik, hal ini harus dijadikan suatu yang harus dibenahi Siklus II.

\section{SIKLUS II}

Peneliti melakukan perbaikan pembelajaran pada siklus II yang meliputi Rencana Perbaikan Pembelajaran (RPP) dan lembar soal kelompok serta bahan ajar sesuai metode yang digunakan. Hal-hal tersebut nantinya akan dijadikan sebagai acuan cara melihat karakter siswa dan penilaian kinerja siswa melalui lembar observasi pada refleksi Siklus I. 
PTK, Vol.2 No.1 2021

ISSN: 2747-1977 (Print) / 2747-1969 (Online)

DOI: https://doi.org/10.53624/ptk.v2i1.44

Berdasarkan pelaksanaan perbaikan pembelajaran tersebut, diperoleh hasil siswa sebagai berikut :

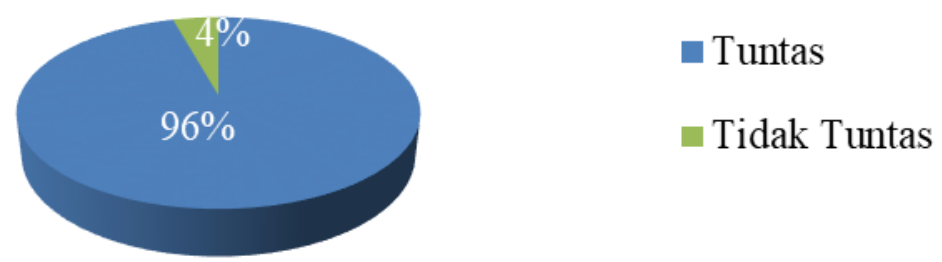

Gambar 3. Ketuntasan Belajar Siswa Tahap Siklus III

Berdasarkan Gambar 3 dapat disimpulkan bahwa perbandingan nilai menunjukkan peningkatan yang sangat memuaskan yaitu 65. Siswa yang mencapai KKM adalah 18 siswa (96\%). Nilai rata-rata siswa kelas IV SD Negeri 1 Joho pada siklus 2 adalah 75.

Berdasarkan data dari hasil tes formatif siklus II ,Nilai siswa mengalami peningkatan yang baik dibandingkan dengan nilai pada siklus I. Pada siklus 2 masih ada 1 siswa yang belum tuntas. Siswa ini adalah siswa yang sama pada pra siklus, siklus I dan siklus II. Siswa yang belum tuntas tersebut sebenarnya dari setiap siklus mengalami peningkatan, Akan tetapi belum dapat mencapai KKM yang ditentukan. Kemudian hasil observasi pengamatan siswa juga sudah bisa dikatakan baik dan dengan demikian tidak perlu dilakukan perbaikan pada siklus II.

Berdasarkan data di atas dapat diketahui bahwa prosentase pra siklus adalah $30 \%$ akan tetapi belum sepenuhnya menerapkan metode. Peningkatan prosentase yang cukup baik yaitu pada siklus I adalah $65 \%$ mengalami peningkatan $30 \%$ dan prosentase siklus 2 yang sudah sepenuhnya menerapkan metode STAD adalah $96 \%$ mengalami peningkatan $31 \%$. Prestasi belajar siswa mengalami peningkatan yang baik di setiap siklusnya. Hasil penelitian yang diperoleh tersebut, menunjukkan bahwa meningkatnya prestasi belajar ini dipengaruhi dengan penggunaan metode yang baik yaitu STAD dengan media konkret. Pembelajaran dengan menggunakan metode ini membuat siswa menjadi tertarik sehingga dapat menumbuhkan semangat siswa.

\section{KESIMPULAN}

Berdasarkan hasil dan pembahasan yang telah dilakukan dan diselesaikan oleh peneliti dalam perbaikan pembelajaran maka dapat disimpulkan bahwa dengan menggunakan metode STAD dengan bantuan media konkret dapat meningkatkan prestasi belajar Ilmu Pengetahuan Alam materi fungsi bagian-bagian tumbuhan, jenis-jenis tulang daun dan bagian-bagian daun pada siswa kelas VI SD Negeri 1 Joho. Hal ini dibuktikan dengan peningkatan prestasi belajar siswa 
ISSN: 2747-1977 (Print) / 2747-1969 (Online)

DOI: https://doi.org/10.53624/ptk.v2i1.44

yang ditunjukkan dengan jumlah siswa yang tuntas dari setiap siklusnya yaitu pada pra siklus hanya 30\% (5 siswa) yang mencapai KKM yaitu 65\% target yang telah ditetapkan, sementara rata-rata kelas adalah 57. Pada siklus I ada 12 siswa (65 \%) yang mencapai KKM yaitu 65\% target yang telah ditetapkan sementara rata-rata kelas menjadi 64. Pada siklus II menjadi 18 siswa (96\%) dari KKM 65\% target yang telah ditetapkan, sementara untuk nilai rata-rata kelas sudah meningkat menjadi 75. Hasil Ini menunjukan bahwa ketuntasan klasikal telah tercapai $96 \%$ melebihi target $85 \%$ yang telah ditetapkan.

\section{DAFTAR PUSTAKA}

Lubis, Maulana Arafat. 2020. Pembelajaran Tematik SD/MI. Prenada Media. Iskandar. 2009. Penelitian Tindakan Kelas . Ciputat : Gaung Persada.

Simarmata, Janner, Rika Aida Hanum, Dewi Situmorang, Maria Sitorus, Riska Arifin Lubis, Nurul Fazila, Nur Fadilah, Kharisma Paramita, Karen Nathashiah Hasibuan, Rani Sartika Sembiring, and others. 2020. Elemen-Elemen Multimedia Untuk Pembelajaran. Yayasan Kita Menulis.

Slavin, R. E. 2010. Cooperative Learning Teori, Riset dan Praktik. Bandung: Nusa Media

Trianto. 2007. Model - model Pembelajaran Inovatif Berorientasi Kontruktivisme. Jakarta: Prestasi Pustaka Publisher

Trianto. 2009. Mendesain Model Pembelajaran Inovatif-Progresif. Jakarta: Kencana Prenada Media Group. 